\title{
Pengaruh Rasio Keuangan pada Financial Distress
}

\author{
A. A. Istri Agung Mahaningrum ${ }^{1}$ \\ Fakultas Ekonomi dan Bisnis \\ Universitas Udayana, Indonesia
}

\author{
Ni Ketut Lely Aryani Merkusiwati² \\ Fakultas Ekonomi dan Bisnis \\ Universitas Udayana, Indonesia
}

Surel : aaia.mahaningrum@gmail.com

\section{ABSTRAK}

Tujuan penelitian ini adalah untuk memperoleh bukti empiris mengenai pengaruh rasio keuangan pada financial distress. Penelitian ini dilakukan pada perusahaan sektor industri dasar dan kimia yang terdaftar di Bursa Efek Indonesia periode 2016-2018. Sampel ditentukan menggunakan metode nonprobability sampling dengan teknik purposive sampling. Jumlah sampel yang digunakan sebanyak 39 perusahaan serta keseluruhan data pengamatan selama periode 2016-2018 sebanyak 117 data observasi. Teknik analisis yang digunakan adalah analisis regresi logistik. Berdasarkan hasil penelitian, dinyatakan bahwa rasio likuiditas tidak berpengaruh pada financial distress, rasio leverage berpengaruh positif pada financial distress, rasio profitabilitas berpengaruh negatif pada financial distress, rasio aktivitas tidak berpengaruh pada financial distress dan rasio pertumbuhan tidak berpengaruh pada financial distress.

\section{Kata Kunci: Financial Distress; Rasio Keuangan; Regresi Logistik.}

\section{The Effect of Financial Ratios on Financial Distress}

\section{ABSTRACT}

The purpose of this study is to obtain empirical evidence about the effect of financial ratios on financial distress. This research was conducted on companies in the basic and chemical industry sectors listed on the Indonesia Stock Exchange in the 2016-2018 period. The sample was determined using the nonprobability sampling method with a purposive sampling technique. The number of samples used was 39 companies and the overall observation data for the 20162018 period was 117 observation data. The analysis technique used is logistic regression analysis. Based on the results of the study, it was stated that liquidity ratios had no effect on financial distress, leverage ratios had a positive effect on financial distress, profitability ratios had a negative effect on financial distress, activity ratios had no effect on financial distress and growth ratios had no effect on financial distress.

Keywords : $\quad$ Financial Distress; Financial Ratios; Logistic Regression.

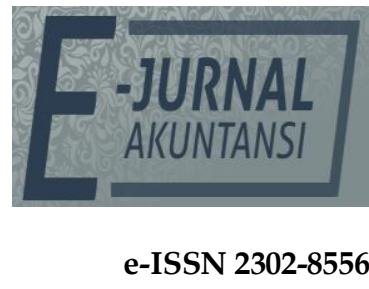

Vol. 30 No. 8

Denpasar, Agustus 2020 Hal. 1969-1984

DOI:

10.24843/EJA.2020.v30.i08.p06

PENGUTIPAN:

Mahaningrum, A. A. I. A. \& Merkusiwati, N. K. L. A. (2020).

Pengaruh Rasio Keuangan pada Financial Distress. E-Jurnal Akuntansi, 30(8), 1969-1984

RIWAYAT ARTIKEL: Artikel Masuk: 17 Januari 2020 Artikel Diterima: 5 Juli 2020

Artikel dapat diakses : https://ojs.unud.ac.id/index.php/Akuntansi/index 


\section{PENDAHULUAN}

Laju pertumbuhan ekonomi global mengalami pelemahan. Perlambatan pertumbuhan ekonomi disebabkan oleh melemahnya aktivitas perdagangan dan manufaktur, ketegangan perdagangan, dan negara berkembang mengalami tekanan pasar serta banyak negara mengalami resesi. Pertumbuhan ekonomi Indonesia juga mengalami penurunan dari tahun sebelumnya (www.kompas.com), (detikfinance.com), dan (www.kompas.com). Perkara kepailitan dan penundaan kewajiban pembayaran utang (PKUP) mengalami peningkatan, hal ini membuat ekonomi nasional terguncang. Ditambah lagi dengan laporan lembaga pemeringkat utang internasional Moody's Investor Service mengungkapkan bahwa perusahan-perusahaan di Indonesia berisiko gagal bayar utang. Perusahaan manufaktur yang paling sering dimohonkan pada PKPU, yaitu perusahaan tekstil, perusahaan garmen, perusahaan baja, dan perusahaan plastik. Terdapat perusahaan yang mengalami masalah keuangan (kontan.co.id) dan (finance.detik.com).

PT Krakatau Steel Tbk (KRAS) mengalami kerugiaan selama 7 tahun berturut-turut, utang menumpuk, isu PHK massal, sampai mundurnya komisaris. PT Solusi Bangunan Indonesia (SMCB) mengalami kerugiaan dari tahun 2016 dan memiliki utang bawaan. PT Dwi Aneka Jaya Kemasindo Tbk (DAJK) dikeluarkan dari Bursa efek Indonesia (BEI) melalui delisting saham. Kinerja keuangan DAJK memang tidak sehat, diketahui memiliki utang dari beberapa bank (www.cnbcindonesia.com), (insight.kontan.co.id), dan (economy.okezone.com). Perusahaan manufaktur yang digunakan adalah perusahaan sektor industri dasar dan kimia. Alasan memilih sektor ini karena perusahaan sering bermasalah pada keuangan dan perusahaan yang disebutkan merupakan bagian dari sektor tersebut. Pada saat ini perusahaan semakin berusaha dalam bersaing dan bertahan pada posisi bisnisnya. Setiap menjalankan akitivitas, perusahaan pasti ada yang berjalan dengan baik maupun tidak berjalan dengan baik. Hal ini biasa terjadi pada perusahaan, namun ada masalah paling dikhawatirkan oleh perusahaan yaitu kesulitan keuangan atau financial distress.

Financial distress merupakan kondisi dimana perusahaan mengalami kesulitan keuangan atau likuidasi yang harus dihadap sebelum terjadinya kebangkrutan. Menurut Shilpa \& Amulya (2017) financial distress didefinisikan sebagai ketidakmampuan perusahaan untuk memenuhi kewajiban keuangannya saat ini. berbagai cara penelitian untuk mengetahui suatu perusahan mengalami kondisi financial distress antara lain menggunakan Interest Coverage Ratios (Asquith et al., 1994), dan (Makeeva \& Khugaeva, 2018), ekuitas negatif (Waqas \& Md-Rus, 2018), debt service coverage ratio (Indriyanti, 2019), earning per share negatif (Mittal \& Lavina, 2018) dan (Witiastuti \& Suryandari, 2016). Perusahaan yang mengalami financial distress dapat dilihat dari beberapa kondisi yaitu EBITDA lebih kecil dari biaya keuangan dalam dua tahun berturut-turut, penurunan market value (nilai pasar) dalam dua tahun berturut-turut, dan Operating Cash Flow kurang dari biaya keuangan dalam dua tahun berturut-turut (Gupta et al., 2019), (Manzaneque et al., 2016), (Pindado et al., 2008), dan (Rezende et al., 2017). Suatu perusahaan maupun Usaha Kecil dan Menengah (UKM) diklasifikasikan sebagai tertekan secara finansial jika kondisi antara lain EBITDA 
2 tahun berturut-turut < biaya keuangan, (kekayaan bersih/ total utang) $<1$ dan kekayaan bersih turun diantara dua periode (Keasey et al., 2015).

Teori yang digunakan adalah signaling theory dan trade-off theory. Signaling theory diciptakan oleh Spence (1973), menurut Harmadji et al. (2018) signaling theory merupakan bentuk sinyal keberhasilan atau kegagalan suatu perusahaan. Teori ini berkaitan dengan informasi asimetris dimana satu pihak mempunyai informasi lebih lengkap dibandingkan dengan pihak lain. Menurut Gantyowati \& Nugraheni (2014) perusahaan memberikan informasi dalam bentuk laporan keuangan kepada pihak lain ada dua jenis sinyal yaitu berita baik dan berita buruk. Jika perusahaan memberikan berita baik maka memberikan kesan baik kepada investor dan meningkatkan nilai dan harga saham perusahaan, tetapi bila perusahaan memberikan berita buruk akan lebih sedikit memberikan informasinya. Teori struktur modal berawal dibuat oleh Modigliani \& Miller (1963). Menurut Wiagustini et al. (2017) teori MM ini melahirkan dua teori yaitu pecking order theory dan trade-off theory. Dalam penelitian ini, teori yang digunakan adalah trade-off theory. Trade-off theory merupakan teori yang dimana perusahaan harus seimbang antara manfaat perlindungan pajak dan biaya kesulitan untuk mendapatkan rasio utang yang optimal (Liu, 2017). Menurut Ikpesu (2019) trade-off theory mengungkapkan bahwa penggunaan utang meningkatkan nilai perusahaan. Namun, ada titik tertentu dimana penggunaan lebih dapat tidak menguntungkan dan akan meningkatkan biaya agensi dan biaya kebangkrutan serta mengurangi nilai perusahaan yang dapat mengarah kesulitan keuangan.

Menurut Kasmir (2012:122) rasio keuangan ialah membandingkan angka yang ada dalam laporan keuangan. Rasio keuangan merupakan angka yang diperoleh dari hasil perbandingan dari suatu pos dengan pos lainnya dalam laporan keuangan yang relevan dan signifikan (Harahap, 2011:297). Menurut Maulidina (2014) rasio keuangan dapat melakukan prediksi dengan mencari informasi berupa analisis laporan keuangan dengan rasio keuangan, analisis tersebut memberikan kemungkinan terjadi financial distress pada suatu perusahaan. Tujuan analisis rasio keuangan yaitu memperoleh rasio keuangan dalam memberikan informasi tentang peristiwa kedepan dan dapat digunakan dalam model financial distress atau memprediksi kebangkrutan (Sayari \& Mugan, 2017). Rasio yang digunakan adalah rasio likuiditas, leverage, profitabilitas, aktivitas dan pertumbuhan.

Rasio likuiditas merupakan rasio yang mengukur kemampuan perusahaan dalam membayar kewajiban atau utang pada jatuh tempo (Kasmir, 2012:145). Rasio likuiditas diproksikan menggunakan rasio lancar atau current ratio. Current ratio merupakan kemampuan perusahaan dalam membayar kewajiban atau utang jangka pendek keseluruhannya pada jatuh tempo (Kasmir, 2012:134). Perusahaan dapat dikatakan likuid bila perusahaan dapat menyelesaikan kewajiban jangka pendeknya saat jatuh tempo dengan tepat waktu. Nilai rasio likuiditas tinggi maka perusahaan memiliki kemampuan untuk memenuhi kewajiban jangka pendeknya (Rohmadini et al., 2018). Berdasarkan signaling theory mengungkapkan bahwa semakin tinggi rasio likuiditas, maka kemungkinan perusahaan tidak mengalami financial distress. Ini memberikan sinyal baik bagi investor bahwa perusahaan dalam keadaan sehat dan cocok 
sebagai tempat berinvestasi. Sebaliknya, semakin rendah rasio likuiditas, maka kemungkinan perusahaan akan mengalami financial distress. Ini memberikan sinyal buruk bagi investor bahwa keadaan perusahaan tidak sehat dan kemungkinan terjadi financial distress. Hasil penelitian yang dilakukan oleh Mesak \& Sukartha (2019) menunjukkan bahwa rasio likuiditas berpengaruh negatif pada kondisi financial distress. Hasil penelitian ini sejalan dengan penelitian sebelumnya oleh Widhiari \& Merkusiwati (2015), Damayanti et al., (2017), Curry \& Banjarnahor (2018) serta Antikasari \& Djuminah (2017).

$\mathrm{H}_{1}$ : Rasio likuiditas berpengaruh negatif pada financial distress.

Rasio leverage merupakan rasio yang mengukur perusahaan dalam pengunaan utang pada aset maupun modal (Kasmir, 2012:165). Rasio leverage diproksikan menggunakan debt to equity ratio. Debt to equity ratio merupakan kemampuan perusahaan dalam menutup seluruh hutangnya dengan modal yang mereka miliki (Kasmir, 2012:157). Rasio leverage yang terlalu tinggi menyebabkan perusahaan mempunyai tingkat utang tinggi yang dapat membebani perusahaan pada saat jatuh tempo, sehingga penting bagi perusahaan untuk memerhatikan tingkat leverage (Rohmadini et al., 2018). Berdasarkan signaling theory mengungkapkan bahwa semakin rendah rasio leverage, maka kemungkinan perusahaan tidak mengalami financial distress. Ini memberikan sinyal baik bagi investor bahwa perusahaan dalam keadaan sehat dan cocok sebagai tempat berinvestasi. Sebaliknya, semakin tinggi rasio leverage, maka kemungkinan perusahaan akan mengalami financial distress. Ini memberikan sinyal buruk bagi investor bahwa keadaan perusahaan tidak sehat dan kemungkinan terjadi financial distress. Berdasarkan trade-off theory mengungkapkan bahwa semakin tinggi rasio leverage, maka perusahaan tidak perlu meningkatkan utang secara optimal dan meningkatkan utang dapat menurunkan nilai perusahaan. Bila perusahaan tetap meningkatkan utang maka perusahaan dapat mengalami financial distress, oleh karenanya meningkatkan utang sama saja dengan meningkatkan financial distress. Terdapat hasil penelitian mengenai pengaruh rasio leverage yang menggunakan debt to equity ratio pada financial distress. Hasil penelitian yang dilakukan oleh Agustini \& Wirawati (2019) menunjukkan bahwa rasio leverage berpengaruh positif pada kondisi financial distress. Hasil penelitian ini sama dengan penelitian sebelumnya oleh (Dewi \& Dana 2017), (Mesak \& Sukartha, 2019), (Maulida et al. 2018), (Hendra et al. 2018), (Harianti \& Paramita, 2019), serta (Wulansari \& Diana, 2017).

$\mathrm{H}_{2}$ : Rasio leverage berpengaruh positif pada financial distress.

Rasio profitabilitas merupakan rasio yang mengukur kemampuan perusahaan dalam meningkatkan keuntungan (Kasmir, 2012:210). Rasio profitabilitas diproksikan menggunakan tingkat pengembalian aset atau return on asset. Return on asset merupakan kemampuan perusahaan dalam mencari keuntungan berupa laba yang didapatkan dari aktiva (Harahap, 2011:305). Perusahaan dengan rasio profitabilitas yang tinggi maka perusahaan memiliki kemampuan keuangan yang cukup untuk memenuhi kebutuhan operasionalnya. Jumlah laba yang besar menunjukkan bahwa perusahaan tidak akan mengalami financial distress (Sudaryanti \& Dinar, 2019). Berdasarkan signaling theory mengungkapkan bahwa semakin tinggi rasio profitabilitas, maka kemungkinan perusahaan tidak mengalami financial distress. Ini memberikan sinyal baik bagi 
investor bahwa perusahaan dalam keadaan sehat dan cocok sebagai tempat berinvestasi. Sebaliknya, semakin rendah rasio profitabilitas, maka kemungkinan perusahaan akan mengalami financial distress. Ini memberikan sinyal buruk bagi investor bahwa keadaan perusahaan tidak sehat dan kemungkinan terjadi financial distress. Hasil penelitian yang dilakukan oleh Agustini \& Wirawati (2019) menunjukkan bahwa rasio profitabilitas berpengaruh negatif pada kondisi financial distress. Hasil penelitian ini sejalan dengan penelitian sebelumnya oleh (Dewi \& Dana, 2017), (Mesak \& Sukartha, 2019), (Damayanti et al., 2017), (Curry \& Banjarnahor, 2018), (Hendra et al, 2018), serta (Harianti \& Paramita, 2019).

$\mathrm{H}_{3}$ : Rasio profitabilitas berpengaruh negatif pada financial distress.

Rasio aktivitas merupakan rasio yang digunakan untuk mengukur kemampuan perusahaan dalam pemanfaatan sumber daya yang dimiliki dengan efisien (Kasmir, 2012:188). Rasio aktivitas diproksikan menggunakan total asset turn over. Total asset turn over merupakan kemampuan perusahaan dalam menggunakan semua asset yang dimiliki untuk bisa menghasilkan penjualan dengan maksimal (Harahap, 2011:309). Semakin efektif suatu perusahaan menggunakan asetnya untuk menghasilkan penjualan dapat memberikan keuntungan bagi perusahaan. perusahaan tidak efektif dalam penggunaan aset maka mengakibatkan perusahaan mengalami kesulitan keuangan potensial, hal ini menggambarkan kinerja perusahaan tidak baik karena tidak dapat menghasilkan volume penjualan yang cukup dibandingkan dengan investasi pada asetnya (Restianti \& Agustina, 2018). Berdasarkan signaling theory mengungkapkan bahwa semakin tinggi rasio aktivitas, maka kemungkinan perusahaan tidak mengalami financial distress. Ini memberikan sinyal baik bagi investor bahwa perusahaan dalam keadaan sehat dan cocok sebagai tempat berinvestasi. Sebaliknya, semakin rendah rasio aktivitas, maka kemungkinan perusahaan akan mengalami financial distress. Ini memberikan sinyal buruk bagi investor bahwa keadaan perusahaan tidak sehat dan kemungkinan terjadi financial distress. Hasil penelitian yang dilakukan oleh Agustini dan Wirawati (2019) menunjukkan bahwa rasio aktivitas berpengaruh negatif pada kondisi financial distress. Hasil penelitian ini sejalan dengan penelitian sebelumnya oleh (Dewi \& Dana, 2017), (Antikasari \& Djuminah, 2017), (Kartika \& Hasanudin, 2019), serta (Widhiari \& Merkusiwati, 2015). Berdasarkan atas teori dan penelitian terdahulu, maka dapatlah dirumuskan hipotesis sebagai berikut.

$\mathrm{H}_{4}$ : Rasio aktivitas berpengaruh negatif pada financial distress.

Rasio pertumbuhan merupakan rasio yang mengukur kemampuan perusahaan dalam peningkatan pertumbuhannya dari tahun ke tahun (Kasmir, 2012:107). Rasio pertumbuhan diproksikan menggunakan rasio pertumbuhan penjualan atau sales growth. Sales growth merupakan kemampuan perusahaan dalam peningkatan penjualan dengan membandingkan tahun ini dengan tahun lalu (Harahap, 2011:309). Semakin tinggi pertumbuhan penjualan maka perusahaan berhasil menjalankan aktivitas serta laba yang dihasilkan, dan akan berpengaruh pada bertambahnya arus kas perusahaan, sehingga pada kondisi keuangan perusahaan akan membaik. Perusahaan dengan kondisi keuangan yang baik berarti tidak akan mengalami kesulitan keuangan (Muflihah, 2017). Berdasarkan signaling theory mengungkapkan bahwa semakin tinggi rasio pertumbuhan, maka kemungkinan perusahaan tidak mengalami financial distress. 
Ini memberikan sinyal baik bagi investor bahwa perusahaan dalam keadaan sehat dan cocok sebagai tempat berinvestasi. Sebaliknya, semakin rendah rasio pertumbuhan, maka kemungkinan perusahaan akan mengalami financial distress. Ini memberikan sinyal buruk bagi investor bahwa keadaan perusahaan tidak sehat dan kemungkinan terjadi financial distress. Hasil penelitian yang dilakukan oleh Lubis \& Patrisia (2019) menunjukkan bahwa rasio pertumbuhan berpengaruh negatif pada kondisi financial distress. Hasil penelitian ini sejalan dengan penelitian sebelumnya oleh (Widhiari \& Merkusiwati, 2015), (Yudiawati \& Indriani, 2016), serta (Setyowati \& Sari, 2019). Berdasarkan penjelasan sebelumnya, maka dapat dirumuskan hipotesis sebagai berikut.

$\mathrm{H}_{5}$ : Rasio pertumbuhan berpengaruh negatif pada financial distress.

Berdasarkan dari di atas, maka dapat diketahui kerangka konseptual dalam penelitian ini dapat dilihat pada gambar 1 sebagai berikut.

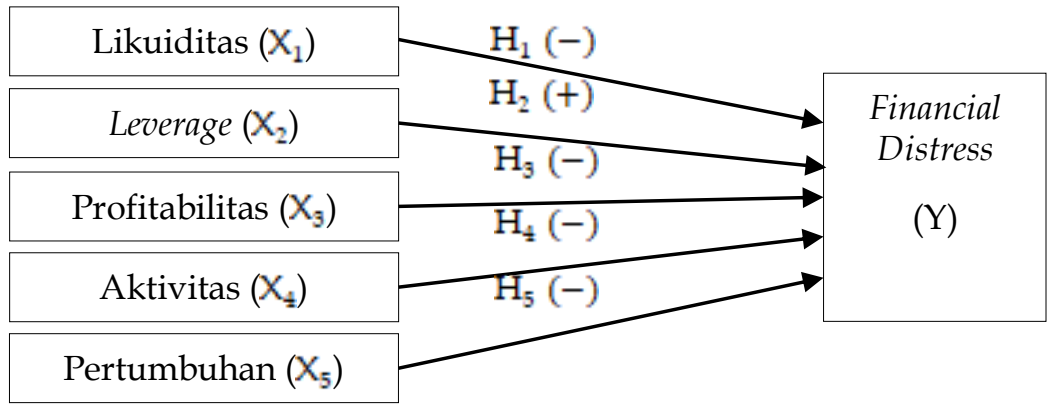

Gambar 1. Kerangka Konseptual

Sumber: Data Penelitian, 2019

\section{METODE PENELITIAN}

Penelitian dilakukan pada perusahaan sektor industri dasar dan kimia yang terdaftar di Bursa Efek Indonesia, hal ini dikarenakan terdapat beberapa perusahaan pada sektor tersebut mengalami masalah pada keuangannya. Perusahaan sektor industri dasar dan kimia serta laporan keuangan dapat diakses pada Bursa Efek Indonesia melalui website www.idx.co.id atau www.idnfinancials.com maupun mengakses situs resmi perusahaan.

Variabel dependen yang digunakan adalah financial distress. Penelitian ini mengadaptasi penelitian sebelumnya menurut Asquith et al. (1994), Pindado et al. (2008) dan Gupta et al. (2019), yang dimana perusahaan dikatakan mengalami financial distress apabila perusahaan tersebut mengalami beberapa kondisi yaitu sebagai berikut.

Interest Coverage Ratio (Asquith et al., 1994). Rumus Interest Coverage Ratio (Brigham \& Houston, 2015:144):

Interest Covernge Ratio $=\frac{\text { EBIT }}{\text { Beban Bunga }}$....

Laba sebelum bunga, pajak, depresiasi, dan amortisasi (EBITDA) lebih kecil dari biaya keuangan dalam dua tahun berturut-turut (Pindado et al., 2008). Nilai EBITDA lebih kecil dari biaya keuangan dapat dilihat sebagai berikut.

EBITDA $<$ Biaya kenangan 
Penurunan market value dalam dua tahun berturut-turut (Pindado et al., 2008). Rumus Market value sebagai berikut (Susetyo \& Niati, 2018).

Market Value $=$ harga saham penutupan $\mathrm{x}$ jumlah saham yang beredar

Operating Cash Flow (OCF) kurang dari biaya keuangan dalam dua tahun berturut-turut (Gupta et al., 2019). Nilai OCF kurang dari biaya keuangan dapat dilihat sebagai berikut.

$O C F<$ Biaya ketuangan.

Penelitian ini menggunakan variabel dummy, maka perusahaan yang memenuhi salah satu dari empat kondisi tersebut sebagai perusahaan mengalami financial distress (FD) diberi kode 1, sedangkan perusahaan yang tidak mengalami financial distress (TFD) diberi kode 0 .

Variabel independen yang digunakan adalah rasio likuiditas, leverage, profitabilitas, rasio aktivitas, dan rasio pertumbuhan. Cara menghitung masingmasing rasio adalah sebagai berikut.

Rasio likuiditas diproksikan dengan menggunakan Current Ratio (CR). Current Ratio dapat dirumuskan sebagai berikut (Kasmir, 2012:146):

Current Ratio $=\frac{\text { Aset Lancar }}{\text { Utang Lancas }}$

Rasio leverage diproksikan dengan menggunakan Debt to Equity Ratio (DER). Debt to Equity Ratio dapat dirumuskan sebagai berikut (Kasmir, 2012:158):

\section{Debt to Equity Ratio $=\frac{\text { Total Hutang }}{\text { Total Ekuitas }}$}

Rasio profitabilitas diproksikan dengan menggunakan Return on Asset (ROA). Return on Asset dapat dirumuskan sebagai berikut (Harahap, 2011:305):

Return On Asset $=\frac{\text { Laba Bersilh }}{\text { Total Aktiva }}$....

Rasio aktivitas diproksikan dengan menggunakan Total Asset Turn Over (TATO). Total Asset Turn Over dapat dirumuskan sebagai berikut (Harahap, 2011:309):

Total assets turnover $=\frac{\text { Penjualan }}{\text { Total Aset }}$.

Rasio pertumbuhan diproksikan dengan menggunakan Sales Growth (SG). Sales Growth dapat dirumuskan sebagai berikut (Harahap, 2011:309):

$$
\text { Sales Growth }=\frac{\text { Penjualan Tahun Iri-Penjualan Tahuu Lalu }}{\text { Penjualan Tahun Lalu }} \text {.... }
$$

Sumber data dalam penelitian ini adalah sumber data sekunder yang berupa laporan keuangan tahunan perusahaan sektor industri dasar dan kimia yang terdaftar di Bursa Efek Indonesia periode 2016-2018. Populasi pada penelitian ini adalah perusahaan sektor industri dasar dan kimia yang terdaftar di Bursa Efek Indonesia untuk periode 2016-2018. Teknik pengambilan sampel menggunakan nonprobability sampling dengan purposive sampling. Metode pengumpulan data yang digunakan pada penelitian ini adalah dokumentasi. Teknik analisis data menggunakan statistik deskriptif sebagai mendeskripsikan data, analisi uji asumsi klasik untuk mengetahui variabel ada tidaknya masalah sebelum diregresi dengan memakai uji multikolonieritas, serta analisis regresi logistik untuk menguji probabilitas terjadinya variabel terikat dapat diprediksi dengan variabel bebas, adapun tahapannya yaitu uji hosmer and lemeshow's 
goodness of fit test, uji kelayakan keseluruhan model, uji koefisien determinasi, dan uji matriks klasifikasi. Persamaan regresi logistik adalah sebagai berikut.

$\operatorname{Ln} \frac{\mathbb{P}}{1-P}=\alpha+b_{1} X_{1}+b_{2} X_{2}+b_{3} X_{3}+b_{4} X_{4}+b_{5} X_{5}+\varepsilon$

Keterangan:

$\operatorname{Lin} \frac{P}{1-F}=$ Dummy variabel financial distress

$\alpha=$ konstanta persamaan regresi

$\mathrm{b}_{1}, \mathrm{~b}_{2}, \mathrm{~b}_{3}, \mathrm{~b}_{4}, \mathrm{~b}_{5}=$ koefisien regresi

$\mathrm{X}_{1}=$ rasio likuiditas

$\mathrm{X}_{2}=$ rasio leverage

$\mathrm{X}_{3}=$ rasio profitabilitas

$\mathrm{X}_{4}=$ rasio aktivitas

$\mathrm{X}_{5}=$ rasio pertumbuhan

$\varepsilon=$ error

\section{HASIL DAN PEMBAHASAN}

Populasi pada penelitian ini adalah perusahaan sektor industri dasar dan kimia yang terdaftar di Bursa Efek Indonesia. Berdasarkan proses dan hasil seleksi sampel diperoleh sampel sebanyak 39 perusahaan serta keseluruhan data pengamatan selama periode 2016-2018 sebanyak 117 pengamatan. Hasil uji statistik deskriptif financial distress pada Tabel 1, sebagai berikut.

Tabel 1. Hasil Uji Statistik Deskriptif Financial Distress

\begin{tabular}{llllll}
\hline & & Frequency & Percent & Valid Percent & Cumulative Percent \\
\hline Valid & TFD & 86 & 73.5 & 73.5 & 73.5 \\
& FD & 31 & 26.5 & 26.5 & 100.0 \\
& Total & 117 & 100.0 & 100.0 & \\
\hline
\end{tabular}

Sumber: Data Penelitian, 2019

Berdasarkan pada Tabel 1, menunjukkan bahwa terdapat perusahaan yang tidak mengalami financial distress (TFD) sebanyak 86 dan perusahaan yang mengalami financial distress (FD) sebanyak 31. Hasil uji statistik deskriptif rasio likuiditas, leverage, profitabilitas, aktivitas, dan pertumbuhan pada Tabel 2, adalah sebagai berikut.

Tabel 2. Hasil Uji Statistik Deskriptif Rasio Likuiditas, Leverage, Profitabilitas, Aktivitas, dan Pertumbuhan

\begin{tabular}{lllllll}
\hline & $\mathrm{N}$ & $\begin{array}{l}\text { Likuiditas } \\
(\mathrm{CR})\end{array}$ & $\begin{array}{l}\text { Leverage } \\
\text { (DER) }\end{array}$ & $\begin{array}{l}\text { Profitabilitas } \\
\text { (ROA) }\end{array}$ & $\begin{array}{l}\text { Akitivitas } \\
\text { (TATO) }\end{array}$ & $\begin{array}{l}\text { Pertumbuhan } \\
\text { (SG) }\end{array}$ \\
\hline Minimum & 117 & 0.0526 & 0.1092 & -0.1585 & 0.0027 & -0.9801 \\
Maximum & 117 & 6.5022 & 10.7769 & 0.1646 & 8.4293 & 0.8589 \\
Mean & 117 & 1.924827 & 1.656355 & 0.029903 & 1.091629 & 0.099261 \\
Std. & 117 & 1.3249344 & 1.7996269 & 0.0543066 & 1.0240541 & 0.2066980 \\
Deviation & & & & & & \\
N Valid & 117 & & & & & \\
\hline
\end{tabular}

Sumber: Data Penelitian, 2019

Hasil statistik deskriptif variabel rasio likuiditas (X1) menunjukkan bahwa nilai minimum sebesar 0.0526 , nilai maksimum sebesar 6.5022 , nilai mean sebesar 1.924827 dan nilai standar deviasi sebesar 1.3249344. Hasil nilai standar deviasi lebih rendah dari nilai mean, hal ini menunjukkan bahwa adanya sebaran data 
yang bervariansi semakin kecil, atau adanya kesenjangan yang begitu kecil dari nilai minimum dan maksimum.

Hasil statistik deskriptif variabel rasio leverage (X2) menunjukkan bahwa nilai minimum sebesar 0.1092 , nilai maksimum sebesar 10.7769 , nilai mean sebesar 1.656355 dan nilai standar deviasi sebesar 1.7996269. Hasil nilai standar deviasi lebih tinggi dari nilai mean, hal ini menunjukkan bahwa adanya sebaran data yang bervariansi semakin besar, atau adanya kesenjangan yang begitu besar dari nilai minimum dan maksimum.

Hasil statistik deskriptif variabel rasio profitabilitas (X3) menunjukkan bahwa nilai minimum sebesar -0.1585 , nilai maksimum sebesar 0.1646 , nilai mean sebesar 0.029903 dan nilai standar deviasi sebesar 0.0543066 . Hasil nilai standar deviasi lebih tinggi dari nilai mean, hal ini menunjukkan bahwa adanya sebaran data yang bervariansi semakin besar, atau adanya kesenjangan yang begitu besar dari nilai minimum dan maksimum.

Hasil statistik deskriptif variabel rasio akitivitas (X4) menunjukkan bahwa nilai minimum sebesar 0.0027 , nilai maksimum sebesar 8.4293 , nilai mean sebesar 1.091629 dan nilai standar deviasi sebesar 1.0240541. Hasil nilai standar deviasi lebih rendah dari nilai mean, hal ini menunjukkan bahwa adanya sebaran data yang bervariansi semakin kecil, atau adanya kesenjangan yang begitu kecil dari nilai minimum dan maksimum.

Hasil statistik deskriptif variabel rasio pertumbuhan (X5) menunjukkan bahwa nilai minimum sebesar -0.9801 , nilai maksimum sebesar 0.8589 , nilai mean sebesar 0.099261 dan nilai standar deviasi sebesar 0.2066980. Hasil nilai standar deviasi lebih tinggi dari nilai mean, hal ini menunjukkan bahwa adanya sebaran data yang bervariansi semakin besar, atau adanya kesenjangan yang begitu besar dari nilai minimum dan maksimum. Hasil uji analisis asumsi klasik yang digunakan adalah uji multikolonieritas yang dapat dilihat pada Tabel 3 sebagai berikut:

Tabel 3. Hasil Uji Multikolonieritas

\begin{tabular}{llllllll}
\hline \multicolumn{1}{l}{$\begin{array}{l}\text { Step } \\
1\end{array}$} & Constant & Constant & X1 & X2 & X3 & X4 & X5 \\
& & & -0.800 & -0.687 & 0.444 & 0.046 & -0.231 \\
& X1 & -0.800 & 1.000 & 0.644 & -0.631 & -0.251 & 0.194 \\
& & & & & & \\
X2 & -0.687 & 0.644 & 1.000 & -0.628 & -0.553 & 0.465 \\
X3 & 0.444 & -0.631 & -0.628 & 1.000 & 0.115 & -0.158 \\
& & & & & & \\
X4 & 0.046 & -0.251 & -0.553 & 0.115 & 1.000 & -0.652 \\
& & & & & & \\
X5 & -0.231 & 0.194 & 0.465 & 0.158 & -0.652 & 1.000 \\
\hline
\end{tabular}

Sumber: Data Penelitian, 2019

Berdasarkan pada Tabel 3, dapat disimpulkan bahwa tidak ada gejala multikolonieritas antar variabel independen. Hal ini dikarenakan bahwa nilai independen kurang dari 0.90. Hasil Uji Hosmer and Lemeshow's Goodness of fit Test dapat dilihat pada tabel 4 sebagai berikut. 
Tabel 4. Hasil Uji Hosmer and Lemeshow's Goodness of fit Test

\begin{tabular}{llcc}
\hline Step & Chi-square & $\mathrm{df}$ & Sig. \\
\hline 1 & 10.415 & 8 & 0.237
\end{tabular}

Sumber: Data Penelitian, 2019

Berdasarkan pada Tabel 4, menunjukkan bahwa nilai chi-square sebesar 10,415 dan nilai signifikansi sebesar 0.237. Berdasarkan hasil tersebut, nilai signifikansi sebesar $0.237>0.05$, maka dapat disimpulkan bahwa model mampu memprediksi dan dapat diterima dengan data observasi. Hasil uji kelayakan keseluruhan model dapat dilihat pada Tabel 5, sebagai berikut.

Tabel 5. Hasil Uji kelayakan keseluruhan model

\begin{tabular}{lll}
\hline Hasil & Iteration & - 2 Log Likelihood \\
\hline Nilai - 2 LogL pada awal (Block Number $=0)$ & Step 0 & 135.294 \\
Nilai - 2 LogL pada akhir (Block Number $=1)$ & Step 1 & 48.112
\end{tabular}

Sumber: Data Penelitian, 2019

Hasil uji kelayakan keseluruhan model menunjukkan bahwa nilai 2LogL pada akhir (block number $=1$ ) sebesar 48.112 lebih rendah dari nilai - 2 LogL pada awal (block number $=0$ ) sebesar 135.294. Berdasarkan hasil uji kelayakan keseluruhan model dapat disimpulkan bahwa model fit dengan data. Hasil uji koefisien determinasi dapat dilihat pada Tabel 6 sebagai berikut.

Tabel 6. Hasil Uji Koefisien Determinasi

\begin{tabular}{llll}
\hline Step & - 2 Log likelihood & Cox \& Snell R Square & Nagelkerke R Square \\
\hline 1 & $48.112^{\mathrm{a}}$ & 0.525 & 0.766
\end{tabular}

Sumber: Data Penelitian, 2019

Berdasarkan pada Tabel 6, menunjukkan bahwa nilai Cox $\mathcal{E}$ Snell $R$ Square sebesar 0,525 dan nilai Nagelkerke $R$ Square sebesar 0.766 yang berarti variabilitas variabel dependen yang dapat dijelaskan oleh variabel independen sebesar 76.6 persen dan sisanya sebesar 23.4 persen dijelaskan oleh variabilitas variabelvariabel lain di luar model penelitian. Hasil Uji Matriks Klasifikasi dapat dilihat pada tabel 7 sebagai berikut.

Tabel 7. Hasil Uji Matriks Klasifikasi

\begin{tabular}{|c|c|c|c|c|c|}
\hline \multicolumn{3}{|c|}{ Observed } & \multicolumn{3}{|c|}{ Predicted } \\
\hline & & & \multicolumn{2}{|c|}{ FD } & \multirow{2}{*}{$\begin{array}{l}\text { Percentage } \\
\text { Correct }\end{array}$} \\
\hline & & & TFD & FD & \\
\hline \multirow[t]{3}{*}{ Step 1} & FD & TFD & 84 & 2 & 97.7 \\
\hline & & FD & 10 & 21 & 67.7 \\
\hline & $O v t$ & & & & 89.7 \\
\hline
\end{tabular}

Sumber: Data Penelitian, 2019

Berdasarkan pada Tabel 7, menunjukkan bahwa kekuatan prediksi berdasarkan model regresi logistik dalam memprediksi kemungkinan perusahaan yang tidak mengalami financial distress (TFD) sebesar 97.7 persen dan 
kekuatan prediksi dari model regresi logistik dalam memprediksi kemungkinan perusahaan yang mengalami financial distress (FD) sebesar 67.7 persen. Hasil uji analisis regresi logistik dapat dilihat pada Tabel 8 sebagai berikut.

Tabel 8. Hasil Uji Analisis Regresi Logistik

\begin{tabular}{llllllll}
\hline & & B & S.E. & Wald & df & Sig. & Exp (B) \\
\hline Step 1 & X1 & 0.827 & 0.521 & 2.518 & 1 & 0.113 & 2.287 \\
& X2 & 1.310 & 0.476 & 7.567 & 1 & 0.006 & 3.707 \\
& X3 & -114.152 & 36.924 & 9.558 & 1 & 0.002 & 0.000 \\
& X4 & -1.104 & 0.908 & 1.480 & 1 & 0.224 & 0.331 \\
& X5 & 2.807 & 3.009 & 0.870 & 1 & 0.351 & 16.559 \\
& Constant & -2.377 & 1.273 & 3.488 & 1 & 0.062 & 0.093 \\
\hline
\end{tabular}

Sumber: Data Penelitian, 2019

Hasil persamaan regresi logistik dapat dilihat sebagai berikut.

$\operatorname{Ln} \frac{\mathrm{P}}{1-\mathrm{P}}=-2.377+0.827 \mathrm{X}_{1}+1.310 \mathrm{X}_{2}-114.152 \mathrm{X}_{3}-1.104 \mathrm{X}_{4}+2.807 \mathrm{X}_{5}+\varepsilon$

Nilai koefisien rasio likuiditas sebesar 0.827 dan nilai signifikansi sebesar 0.113 atau lebih besar dari 0.05, dengan demikian hipotesis 1 ditolak. Hasil penelitian ini membuktikan bahwa rasio likuiditas tidak berpengaruh pada financial distress. Hasil penelitian ini sesuai dengan hasil penelitian oleh Dewi \& Dana (2017), Agustini \& Wirawati (2019), Maulida et al. (2018), serta Aisyah et al. (2017) yang menyatakan bahwa rasio likuiditas tidak berpengaruh pada financial distress.

Nilai koefisien variabel leverage sebesar 1.310 dan nilai signifikansi sebesar 0.006 atau lebih kecil dari 0.05, dengan demikian hipotesis 2 diterima. Hasil penelitian ini membuktikan bahwa rasio leverage berpengaruh positif terhadap financial distress. Hasil penelitian ini sesuai dengan hasil penelitian oleh Dewi \& Dana (2017), Agustini \& Wirawati (2019), Mesak \& Sukartha (2019), Maulida et al. (2018), Hendra et al. (2018), Harianti \& Paramita (2019), serta Wulansari \& Diana (2017) yang menyatakan bahwa rasio leverage berpengaruh positif pada financial distress.

Nilai koefisien variabel profitabilitas sebesar -114.152 dan nilai signifikansi sebesar 0.002 atau lebih kecil dari 0.05, dengan demikian hipotesis 3 diterima. Hasil penelitian ini membuktikan bahwa rasio profitabilitas berpengaruh negatif pada financial distress. Hasil penelitian ini sesuai dengan hasil penelitian oleh Dewi \& Dana (2017), Agustini \& Wirawati (2019), Mesak \& Sukartha (2019), Damayanti et al. (2017), Curry \& Banjarnahor (2018), Hendra et al. (2018), serta Harianti \& Paramita (2019) yang menyatakan bahwa rasio profitabilitas berpengaruh negatif pada financial distress.

Nilai koefisien variabel aktivitas sebesar -1.104 dan nilai signifikansi sebesar 0.224 atau lebih besar dari 0.05, dengan demikian hipotesis 4 ditolak. Hasil penelitian ini membuktikan bahwa rasio aktivitas tidak berpengaruh pada financial distress. Hasil penelitian ini sesuai dengan hasil penelitian oleh Rahmy (2015), Shidiq \& Khairunnisa (2019), Setiawan \& Amboningtyas (2018), serta Aisyah et al. (2017) yang menyatakan bahwa rasio aktivitas tidak berpengaruh pada financial distress.

Nilai koefisien variabel pertumbuhan sebesar 2.807 dan nilai signifikansi sebesar 0.351 atau lebih besar dari 0.05, dengan demikian hipotesis 5 ditolak. 
Hasil penelitian ini membuktikan bahwa rasio pertumbuhan tidak berpengaruh pada financial distress. Hasil penelitian ini sesuai dengan hasil penelitian oleh Agustini \& Wirawati (2019), Curry \& Banjarnahor (2018), Rahmy (2015), serta Nurhayati et al. (2019) yang menyatakan bahwa rasio aktivitas tidak berpengaruh pada financial distress.

\section{SIMPULAN}

Berdasarkan hasil dan pembahasan tersebut, maka dapat ditarik simpulan bahwa rasio likuiditas tidak berpengaruh pada financial distress, rasio leverage berpengaruh positif pada financial distress, rasio profitabilitas berpengaruh negative pada financial distress, rasio aktivitas tidak berpengaruh pada financial distress dan pertumbuhan tidak berpengaruh pada financial distress. Manajemen perusahaan diharapkan untuk memerhatikan rasio keuangan seperti rasio leverage, dan rasio profitabilitas, karena rasio tersebut memiliki pengaruh untuk memprediksi financial distress. Memerhatikan tingkat interent coverage ratio, laba bersih perusahaan, market value, dan operating cash flow, bila mengalami penurunan maka menunjukkan bahwa perusahaan sedang mengalami financial distress. Manejemen perusahaan harus mengambil keputusan yang tepat dalam kewajiban utang yang akan jatuh tempo. Penelitian selanjutnya diharapkan menggunakan rasio keuangan lainnya dan menambahkan variabel indenpenden seperti good corporate governance, makroekonomi, dan political risk sebagai faktorfaktor yang memengaruhi financial distress. Periode pengamatan ditambah lebih panjang serta menggunakan perusahaan lainnya yang terdaftar di Bursa Efek Indonesia maupun UKM. Calon investor diharapkan lebih berhati-hati dalam melakukan investasi pada perusahaan sektor industri dasar dan kimia dengan memerhatikan rasio keuangan perusahaan sebagai acuan pertimbangan dalam berinvestasi.

\section{REFERENSI}

Agustini, N. W., \& Wirawati, N. G. P. (2019). Pengaruh Rasio Keuangan Pada Financial Distress Perusahaan Ritel Yang Terdaftar di Bursa Efek Indonesia (BEI). E-Jurnal Akuntansi, 26(1), 251-280. https:// doi.org/10.24843/eja.2019.v26.i01.p10

Aisyah, N. N., Kristanti, F. T., \& Zultilisna, D. (2017). Pengaruh Rasio Likuiditas, Rasio Aktivitas, Rasio Profitabilitas, dan Rasio Leverage Terhadap Financial Distress. E-Proceeding of Management, 4(1), 411-419.

Alhikam, H. A. (2019). Ancaman Resesi Dinilai Makin Dekat, Bagaimana di RI? Retrieved September 29, 2019, from detik.com website: https:/ / finance.detik.com/berita-ekonomi-bisnis/d-4726594/ancamanresesi-dinilai-makin-dekat-bagaimana-di-ri

Antikasari, T. W., \& Djuminah, D. (2017). Memprediksi Financial Distress Dengan Binary Logit Regression Perusahaan Telekomunikasi. Jurnal Keuangan Dan Perbankan, 21(2), 265-275. https:// doi.org/10.26905/jkdp.v21i2.654

Arieza, U. (2019). Dwi Aneka Jaya Kemasindo Hengkang dari Bursa, Ini Penjelasan BEI. Retrieved October 3, 2019, from okezone.com website: https://economy.okezone.com/read/2018/05/22/278/1901 
aneka-jaya-kemasindo-hengkang-dari-bursa-ini-penjelasan-bei

Asquith, P., Gertner, R., \& David, S. (1994). Anatomy of Financial Distress: an Examination of Junk-Bond. The Quarterly Journal of Economics, 109(3), 625658. https://doi.org/10.3386/w3942

Brigham, E. f., \& Houston, J. F. (2015). Dasar-Dasar Manajemen Keuangan Edisi 11 Buku 1. Jakarta: Salemba Empat.

Curry, K., \& Banjarnahor, E. (2018). Financial Distress Pada Perusahaan Sektor Properti Go Public di Indonesia. Seminar Nasional Pakar 1, (Buku 2), 207-221.

Damayanti, L. D., Yuniarta, G. A., \& Sinarwati, N. K. (2017). Analisis Pengaruh Kinerja Keuangan, Ukuran Komite Audit Dan Kepemilikan Manajerial Terhadap Prediksi Financial Distress (Studi Pada Perusahaan Manufaktur Yang Terdaftar Di Bursa Efek Indonesia Periode 2011-2015). E-Journal S1 Ak Universitas Pendidikan Ganesha, 7(1), 1-12.

Dewi, N. K. U. G., \& Dana, M. (2017). Variabel Penentu Financial Distress Pada Perusahaan Manufaktur Di Bursa Efek Indonesia. E-Jurnal Manajemen Unud, 6(11), 5834-5858.

Fauzia, M., \& Djumena, E. (2019). Pertumbuhan Ekonomi RI Melambat, Ini Fakta-faktanya. Retrieved September 29, 2019, from kompas.com website: https://money.kompas.com/read/2019/08/06/ 074200726/pertumbuhanekonomi-ri-melambat-ini-fakta-faktanya?page $=$ all

Fauzia, M., \& Setiawan, S. R. D. (2019). Bank Dunia: Laju Pertumbuhan Ekonomi Global 2019 Melemah. Retrieved July 31, 2019, from kompas.com website: https://money.kompas.com/read/2019/08/06/ 074200726/pertumbuhanekonomi-ri-melambat-ini-fakta-faktanya?page $=$ all

Gantyowati, E., \& Nugraheni, R. L. (2014). The Impact of Financial Distress Status and Corporate Governance Structures on the Level of Voluntary Disclosure Within Annual Reports of Firms (Case Study of Non-financial Firms in Indonesia Over the Period of 2009-2011). Journal of Modern Accounting and Auditing, 10(4), 389-403.

Gupta, J., \& Chaudhry, S. (2019). Mind the tail, or risk to fail. Journal of Business Research, 99, 167-185. https:// doi.org/10.1016/j.jbusres.2019.02.037

Harahap, S. S. (2011). Analisis Kritis Atas Laporan Keuangan. Jakarta: Raja Grafindo Persada.

Harianti, R., \& Paramita, R. A. S. (2019). Analisis faktor internal terhadap financial distress sektor perdagangan, jasa, dan investasi yang go public pada periode 2013 - 2017. Jurnal Ilmu Manajemen, 7(4), 984-993.

Harmadji, D. E., Subroto, B., Saraswati, E., \& Prihatiningtias, Y. W. (2018). From Theory to Practice of Signaling Theory: Sustainability Reporting Strategy Impact on Stock Price Crash Risk with Sustainability Reporting Quality as Mediating Variable. KnE Social Sciences, 3(10), 647-658. https:// doi.org/10.18502/kss.v3i10.3411

Hendra, Afrizal, \& Diah P.A, E. (2018). Faktor-Faktor Yang Mempengaruhi Financial Distress (Studi Empiris Pada Perusahaan Pertambangan yang terdaftar di Bursa Efek Indonesia Periode 2014-2016). Jurnal Akuntansi $\mathcal{E}$ $\begin{array}{ll}\text { Keuangan Unja, } & 3(4) \text {, } \\ \text { https:// doi.org/10.15900/j.cnki.zylf1995.2018.02.001 }\end{array}$

64-74.

Ikpesu, F. (2019). Firm specific determinants of financial distress: Empirical 
evidence from Nigeria. Journal of Accounting and Taxation, 11(3), 49-56. https:// doi.org/10.5897/jat2019.0333

Indriyanti, M. (2019). The Accuracy of Financial Distress Prediction Models: Empirical Study on the World's 25 Biggest Tech Companies in 2015-2016 Forbes's Version. KnE Social Sciences, 3(11), 442. https:// doi.org/10.18502/kss.v3i11.4025

Kartika, R., \& Hasanudin. (2019). Analisis Pengaruh Likuiditas, Leverage, Aktivitas, Dan Profitabilitas Terhadap Financial Distress Pada Perusahaan Terbuka Sektor Infrastruktur, Utilitas, Dan Transportasi Periode 2011-2015. Jurnal Ilmu Manajemen, 15(1), 1-16.

Kasmir. (2012). Analisis Laporan Keuangan. Jakarta: PT. Raja Grafindo Persada.

Keasey, K., Pindado, J., \& Rodrigues, L. (2015). The determinants of the costs of financial distress in SMEs. International Small Business Journal: Researching Entrepreneurship, 33(8), 862-881. https:// doi.org/10.1177/0266242614529317

Liu, W. C. (2017). Trade-off theory of capital structure: Evidence from estimations of non-parametric and semi-parametric panel fixed effect models. Investment Management and Financial Innovations, 14(1), 115-123. https:// doi.org/10.21511/imfi.14(1).2017.12

Lubis, N. H., \& Patrisia, D. (2019). Pengaruh Likuiditas, Leverage, dan Profitabilitas terhadap Financial Distress (Studi Empiris pada Perusahaan Manufaktur yang Terdaftar di BEI periode 2013-2016). Jurnal Kajian Manajemen Dan Wirausaha, 1(1), 173-182. Retrieved from http://ejournal.uajy.ac.id/14649/1/JURNAL.pdf

Makeeva, E., \& Khugaeva, M. (2018). Evaluation of financial distress costs of innovative companies. Russian Management Journal, 16(1), 37-62. https:// doi.org/10.21638/11701/spbu18.2018.102

Manzaneque, M., Priego, A. M., \& Merino, E. (2016). Corporate governance effect on financial distress likelihood: Evidence from Spain. Revista de Contabilidad, 19(1), 111-121. https:// doi.org/10.1016/j.rcsar.2015.04.001

Maulida, I. S., Moehaditoyo, S. H., \& Nugroho, M. (2018). Analisis Rasio Keuangan Untuk Memprediksi Financial Distress Pada Perusahaan Manufaktur Yang Terdaftar Di Bursa Efek Indonesia 2014-2016. Jurnal Ilmiah Administrasi Bisnis Dan Inovasi, 2(1), 179-193. https://doi.org/10.25139/jai.v2i1.1149

Maulidina, D. (2014). Faktor-Faktor Yang Mempengaruhi Financial Distress Pada Perusahaan Manufaktur Yang Terdaftar Di BEI. Media Riset Akuntansi, Auditing E Informasi, 14(3), 89-106.

Mesak, D., \& Sukartha, I. M. (2019). Financial Ratio Analysis in Predicting Financial Conditions Distress in Indonesia Stock Exchange. Russian Journal of Agricultural and Socio-Economic Sciences, 86(2), 155-165. https:// doi.org/10.18551/rjoas.2019-02.18

Mittal, S., \& Lavina. (2018). The Determinant Of Financial Distress In Indian Real Estate And Construction Industry. Gurukul Business Review-GBR, 14, 6-11.

Modigliani, F., \& Miller, M. H. (1958). The Cost of Capital, Corporation Finance and the Theory of Investment. The American Economic Review, 48(3), 261-297. https:// doi.org/10.1136/bmj.2.3594.952

Modigliani, F., \& Miller, M. H. M. (1963). Corporate Income Taxes and the Cost 
of Capital: A Correction. American Economic Review, 53(3), 433-443. https:// doi.org/10.1126/science.151.3712.867-a

Muflihah, I. Z. (2017). Analisis Financial Distress Perusahaan Manufaktur Di Indonesia dengan Regresi Logistik. Majalah Ekonomi, 12(2), 254-269.

Nurhayati, Kania, N., \& Aprian, T. (2019). Pengaruh Sales Growth dan Keahlian Keuangan Komite Audit terhadap Financial Distress (Studi Empiris Pada Perusahaan Manufaktur Sub Sektor Otomotif dan Komponen yang Terdaftar di Bursa Efek IndonesiaPeriode 2012-2016). Kajian Akuntansi, 20(1), 80-86.

Pindado, J., Rodrigues, L., \& de la Torre, C. (2008). Estimating financial distress likelihood. Journal of Business Research, 61(9), 995-1003. https:// doi.org/10.1016/j.jbusres.2007.10.006

Rafael, E. C., \& Gumilar, T. (2019). Jual Tanah, Opsi SMCB Lolos dari Utang Bawaan. Retrieved October 4, 2019, from kontan.co.id website: https://insight.kontan.co.id/news/jual-tanah-opsi-smcb-lolos-dari-utangbawaan

Rahmy, R. (2015). Pengaruh Profitabilitas, Financial Leverage, Sales Growth Dan Aktivitas Terhadap Financial Distress (Studi Empiris pada Perusahaan Manufaktur yang Terdaftar di BEI Tahun 2009-2012). Jurnal Akuntansi, 3(1), 1-31.

Redaksi CNBC Indonesia. (2019). Nasib Miris KS: Rugi 7 Tahun, Isu PHK, dan Komisaris Mundur. Retrieved September 30, 2019, from cnbcindonesia.com website: https://www.cnbcindonesia.com/news/201907240 22425-487047/nasib-miris-ks-rugi-7-tahun-isu-phk-dan-komisaris-mundur

Restianti, T., \& Agustina, L. (2018). The Effect of Financial Ratios on Financial Distress Conditions in Sub Industrial Sector Company. Accounting Analysis Journal, 7(1), 25-33. https://doi.org/10.15294/aaj.v5i3.18996

Rezende, F. F., Da Silva Montezano, R. M., De Oliveira, F. N., \& De Jesus Lameira, V. (2017). Predicting financial distress in publicly-traded companies. Revista Contabilidade e Financas, 28(75), 390-406. https:/ / doi.org/10.1590/1808-057x201704460

Rohmadini, A., Saifi, M., \& Darmawan, A. (2018). Pengaruh Profitabilitas, Likuiditas Dan Leverage Terhadap Financial Distress (Studi Pada Perusahaan Food \& Beverage Yang Terdaftar Di Bursa Efek Indonesia Periode 2013-2016). Jurnal Administrasi Bisnis, 61(2), 11-19.

Sayari, N., \& Mugan, C. S. (2017). Industry specific financial distress modeling. BRQ Business Research Quarterly, 20(1), 45-62. https:// doi.org/10.1016/j.brq.2016.03.003

Septiadi, A., \& Winarto, Y. (2019). Sepanjang 2018, jumlah perkara kepailitan melonjak. Retrieved September 29, 2019, from kontan.co.id website: https://nasional.kontan.co.id/news/sepanjang-2018-jumlah-perkarakepailitan-melonjak

Setiawan, H., \& Amboningtyas, D. (2018). Financial Ratio Analysis For Predicting Financial Distress Conditions (Study on Telecommunication Companies Listed In Indonesia Stock Exchange Period 2010-2016). Journal of Management, 4(4), 1-18.

Setyowati, W., \& Sari, N. R. N. (2019). Pengaruh Likuiditas, Operating Capacity, 
Ukuran Perusahaan Dan Pertumbuhan Penjualan Terhadap Financial Distress (Studi Pada Perusahaan Manufaktur Yang Terdaftar Di BEI Tahun 2016-2017). Jurnal Magisma, 7(2), 135-146.

Shidiq, J. I., \& Khairunnisa. (2019). Analisis Rasio Likuiditas, Rasio Leverage, Rasio Aktivitas, Dan Rasio Pertumbuhan Terhadap Financial Distress Menggunakan Metode Altman Z-Score Pada Sub Sektor Tekstil Dan Garmen Di BEI Periode 2013-2017. JIM UPB, 7(2), 209-219.

Shilpa, N. C., \& Amulya, M. (2017). Corporate Financial Distress: Analysis of Indian Automobile Industry. SDMIMD Journal of Management, 8(1), 47-54. https://doi.org/10.18311/sdmimd/2017/15726

Spence, M. (1973). Job Market Signaling. The Quarterly Journal of Economics, 87(3), 355-374. https:/ / doi.org/10.2307/1882010

Sudaryanti, D., \& Dinar, A. (2019). Analisis Prediksi Kondisi Kesulitan Keuangan Dengan Menggunakan Rasio Likuiditas, Profitabilitas, Financial Leverage Dan Arus Kas. Jurnal Ilmiah Bisnis Dan Ekonomi Asia, 13(2), 101-110. https:// doi.org/10.32812/jibeka.v13i2.120

Susetyo, A., \& Niati, F. (2018). Pengaruh BID-ASK Spread, Market Value Dan Variance Return Terhadap Holding Period Saham. Jurnal Ekonomi Dan Bisnis, 21(1), 1-11.

Tim detikcom. (2019). Hati-hati! Risiko Perusahaan Indonesia Gagal Bayar Utang Meningkat. Retrieved October 4, 2019, from detik.com website: https:// finance.detik.com/ berita-ekonomi-bisnis/d-4728039/hati-hatirisiko-perusahaan-indonesia-gagal-bayar-utang-meningkat

Waqas, H., \& Md-Rus, R. (2018). Predicting financial distress: Applicability of Oscore and logit model for Pakistani firms. Business and Economic Horizons, 14(2), 389-401. https:// doi.org/10.15208/beh.2018.28

Wiagustini, N. L. P., Ramantha, I. W., Panji Sedana, I. B., \& Rahyuda, H. (2017). Indonesia's capital structure: Pecking order theory or trade-off theory. International Journal of Applied Business and Economic Research, 15(16), 119131.

Widhiari, N., \& Aryani Merkusiwati, N. (2015). Pengaruh Rasio Likuiditas, Leverage, Operating Capacity, Dan Sales Growth Terhadap Financial Distress. E-Jurnal Akuntansi, 11(2), 456-469.

Witiastuti, R. S., \& Suryandari, D. (2016). The Influence of Good Corporate Governance Mechanism on the Possibility of Financial Distress. 5(1), 118-127. https:// doi.org/10.2991/insyma-18.2018.19

Wulansari, A. P., \& Diana, N. (2017). Pengaruh Aktivita, Laverage dan Pertumbuhan Perusahaan Dalam Memprediksi Financial Distress ( Studi Empiris Perusahaan Manufaktur Yang Terdaftar Di BEI Tahun 2013-2015. Jurnal Ilmiah Riset Akuntansi, 6(4), 136-146. Retrieved from http:// riset.unisma.ac.id/index.php/jra/article/viewFile/351/392

Yudiawati, R., \& Indriani, A. (2016). Analisis Pengaruh Current Ratio, Debt To Total Asset Ratio, Total Asset Turnover, Dan Sales Growth Ratio Terhadap Kondisi Financial Distress. Diponegoro Journal of Management, 5(2), 1-13. 